
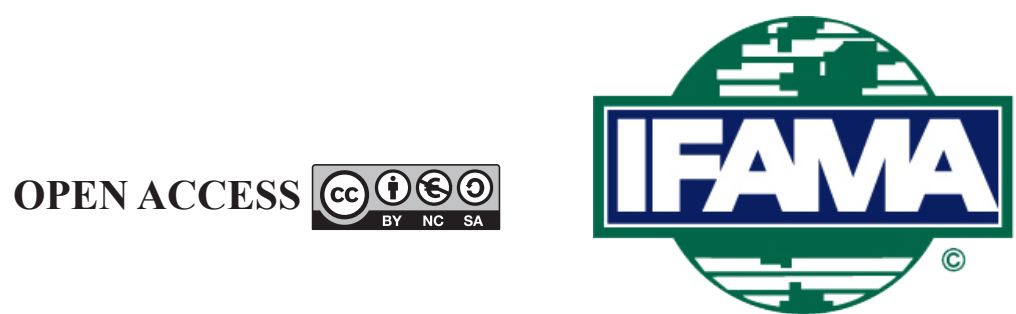

International Food and Agribusiness Management Review

Volume 24, Issue 4, 2021; DOI: 10.22434/IFAMR2019.0184

Received: 7 November 2019 / Accepted: 24 March 2020

Special Issue: Growth of agroholdings and mega-farms in transition and emerging market economies: institutional and organizational aspects

\title{
Corporate governance and firm performance within the Russian agri-food sector: does ownership structure matter? \\ RESEARCH ARTICLE
}

\author{
Alisher Tleubayev $^{(\mathbb{i} a}$, Ihtiyor Bobojonov ${ }^{\mathrm{b}}$, Taras Gagalyuk ${ }^{\mathrm{c}}$, Emma García Meca $^{\mathrm{d}}$ and Thomas Glauben ${ }^{\mathrm{e}}$ \\ ${ }^{a}$ Research Associate, ${ }^{b}$ Senior Researcher, ${ }^{e}$ Professor, Department of Agricultural Markets, \\ Marketing and World Agricultural Trade, Leibniz Institute of Agricultural Development in \\ Transition Economies (IAMO), Theodor-Lieser-Strasse 2, 06120 Halle (Saale), Germany \\ 'Senior Researcher, Department of Structural Development of Farms and Rural \\ Areas, Leibniz Institute of Agricultural Development in Transition Economies \\ (IAMO), Theodor-Lieser-Strasse 2, 06120 Halle (Saale), Germany \\ ${ }^{d}$ Professor, Accounting and Finance Department, Technical University of \\ Cartagena (UPCT), La Milagrosa, Cartagena, 30202 Murcia, Spain
}

\begin{abstract}
This article provides pioneering empirical evidence on the ownership structure and firm performance relationship for the case of corporate agri-food companies in Russia. While Russia plays a vital role in the global agri-food system, its domestic agri-food production is evidently dominated by a small number of corporate enterprises, which are in turn characterized by high ownership concentration. We employ unique panel data obtained from 203 companies for the years between 2012 and 2017. A random effects model was used to analyze the impacts of ownership concentration and ownership identity on the firms' financial performance, measured by return on assets and return on sales. Our results indicate an inverse U-shaped association between ownership concentration and firm performance, with average level of ownership concentration found to be on the descending range of the inverse U-shaped curve. Moreover, we observe a similar quadratic relationship between ownership concentration by government and directors and firm performance. On average, ownership by directors was found to be on the ascending range and below the peak point, suggesting a potential for further performance improvement, while the impact of agroholding ownership was found to be linear and positive.
\end{abstract}

Keywords: corporate governance, ownership structure, agri-food enterprises, firm performance, Russia JEL code: M14, Q12, Q13

${ }^{\circledR}$ Corresponding author: tleubayev@iamo.de 


\section{Introduction}

Russia is one of the world's primary agricultural producers and plays a crucial role in global food security. It is one of the largest global producers of agricultural commodities, such as wheat, barley, sunflower seeds, potatoes, milk, eggs and poultry. Russia is also one of the largest exporters of crops like sunflower seeds, wheat and barley worldwide (USDA, 2018a; Uzun et al., 2019). Moreover, Russia still has enormous potential to boost its agricultural production further and increase the volume and diversity of its exported products. It possesses a huge area of agricultural land of more than 200 million ha and has a supportive climate for agriculture, with its high levels of rainfall and abundance of chernozem (black earth) soil (FAO, 2001, 2017). In addition to its favorable natural conditions, the Russian government is increasingly supporting its domestic agri-food production, with an ultimate aim of expanding the list of exported agri-food products (Wegren et al., 2019). On the one hand, the government has been supporting local production through extensive agricultural subsidization programs. On the other hand, they have been protecting local producers from international competition by restricting agricultural imports through various instruments like import taxes, non-tariff barriers and even an import ban, which was introduced in August 2014 against a number of western countries (Bobojonov et al., 2016; Liefert et al., 2019).

Nowadays, agricultural production in Russia is evidently dominated by large-scale corporate farms (Davydova and Franks, 2015). While the share of corporate farms in the structure of gross agricultural production decreased during the first decade after the collapse of the Soviet Union, this trend has reversed since the end of 1990s (Wegren, 2018). As a result, the share of corporate farms in total agricultural production has increased by around 36\%, from 40.4\% in 1998 to 55.1\% in 2018 (Supplementary Figure S1).

Russian agriculture can be characterized not only by the dominance of corporate farms, but also by a high level of concentration of agri-food production in the hands of a small number of large-scale corporate farms. For instance, 12.6 million ha of land, or $10.5 \%$ of all cultivated land in Russia, is operated by 55 of the largest agri-food companies (BEFL Agency, 2018). A similar situation is observed in the meat and dairy sectors. While the top 25 companies account for almost half (46\%) of the total meat production in the country (Agroinvestor, 2018b), around $60 \%$ of all pork (62\%) and poultry $(58 \%)$ are produced by the top 20 and the top 10 largest companies, respectively (Agroinvestor, 2018a; USDA, 2018b). In the dairy industry, the top 20 companies produce almost $10 \%$ of all raw milk, whereas around $55 \%$ of milk is processed by the top 50 companies (Dairynews, 2018a,b).

Moreover, the Russian corporate system in general is represented by high levels of ownership concentration. According to Iwasaki et al. (2018), in 2015, for approximately $60 \%$ of the corporate companies in Russia, the ownership stakes of the largest shareholders exceeded 50\%. Russian agri-food production is therefore dominated by a small number of large-scale corporate farms, which in turn are controlled by very few shareholders. The sustainability of such a model, whereby the agri-food production is dominated by relatively small number of large-scale corporate farms, which in turn are characterized by highly concentrated ownership, is under question (Deininger and Byerlee, 2012; Hermans et al., 2017). Financial insolvencies by such key players might put the national as well as the global food security at risk. In fact, around 22\% of all bankruptcy cases in Russian agriculture are accounted for by corporate farms (Yastrebova, 2005). It is therefore vital to understand the extent to which the level of ownership concentration in corporate farms affects their financial performance. Moreover, it is also vital to identify whether the ownership identity of the largest shareholders also matters or not, i.e. whether certain types of shareholders are more efficient in taking control of their companies or not. Identifying how ownership structure could contribute to the success of Russian agri-food enterprises is also important for state policy, private investments and other important decisions that might potentially impact the development of the sector. In this study, we focus primarily on three types of ownership identities ${ }^{1}$ that seem to be most relevant in the Russian context (Davydova and

\footnotetext{
${ }^{1}$ The ownership structure of Russian agri-food enterprises is not limited to these three ownership types. There are also agri-food firms owned by other types of shareholders, such as individuals, financial companies and other private entities. However, in this study we specifically focus on state, managerial and agroholding owned companies.
} 
Franks, 2015; Iwasaki et al., 2018): managerial ownership, state ownership and business group (agroholding) ownership, each one representing an ownership identity and ownership share of the largest shareholder.

Indeed there are studies in the corporate governance literature that investigate the relationship between ownership structure and firm performance (e.g. Balsmeier and Czarnitzki, 2017; García-Meca and SánchezBallesta, 2011b). However, these works focus mainly on developed economies with well-functioning corporate governance systems (Kumar and Zattoni, 2019). In the case of a transition country like Russia, such studies are scarce (e.g. Filatotchev et al., 2001). In addition, almost all of the previous research use data from publicly listed companies, making the results of their analyses representative of only a certain share of firms that are active on the stock markets (Balsmeier and Czarnitzki, 2017). Moreover, to the best of our knowledge, studies that focus primarily on agri-food companies are non-existent. Even in the case of non-agri-food enterprises, the corporate governance literature on the relationship between ownership structure and performance is not conclusive. Previous research provides contradicting results, especially in the case of ownership concentration.

While some researchers observe a positive linear relation between ownership concentration and firm performance (Lee, 2008; Nguyen et al., 2015), others find a negative linear connection (Lepore et al., 2017; Setia-Atmaja, 2009), and yet others reveal a non-linear relationship (Balsmeier and Czarnitzki, 2017; García-Meca and Sánchez-Ballesta, 2011b). In any of the cases, the nature of the relationship cannot be $a$ priori theoretically predicted (Sánchez-Ballesta and García-Meca, 2007) and is dependent on a particular empirical context. Therefore, one should probably consider the ownership structure-performance nexus as a matter of empirical research.

This article aims to fill several gaps in the literature: first of all, we provide new empirical evidence to rather ambiguous literature on the relationship between ownership structure and firm performance. Secondly, we expand the literature beyond developed countries with well-settled corporate governance systems and concentrate on a former communist transition country, Russia, which has a short history of a market economy and comparatively less developed corporate governance (Li et al., 2012). In addition, Russia is one of the largest agri-food producers in the world, and plays a vital role in the global food security, which makes this research even more relevant. Lastly, we provide a pioneering study in the context of large-scale corporate agri-food production, which plays an important role in the domestic food security of Russia.

The remainder of the paper is organized as follows: Section 2 provides a conceptual framework and reviews the literature on the ownership structure and firm performance relationship. Methodology and data employed in this study are then described in Section 3, which is followed by the description and discussion of the empirical results in Section 4. Finally, the concluding remarks are presented in Section 5.

\section{Review of literature and hypothesis development}

The subject of ownership structure and its impact on firm performance has been widely debated among scholars for decades and remains an important research agenda today (Iwasaki and Mizobata, 2019). There is a general consensus among researchers that ownership structure, in the form of ownership concentration and ownership identity, might have a significant effect on firm performance. Nevertheless, the nature of this relationship remains unclear, with prior literature suggesting rather mixed results on the matter. While some scholars reveal the link between ownership structure and performance as positive, others find a negative association and yet others observe a more complex, non-linear relationship (Table 1).

Agency theory is the main underlying theory that is widely used in the existing literature for explaining the nexus between ownership concentration and firm performance (Paniagua et al., 2018). According to this theory, low ownership concentration is associated with the principal-agent problem, a conflict between the shareholders (principals) and managers (agents) of the company (Berle and Means, 1932; Jensen and Meckling, 1976). Agency conflict arises when managers pursue desires and goals different from the 
shareholders' (i.e. profit maximization) and therefore do not represent their best interests, as it is difficult and burdensome for the shareholders to verify what the managers are actually doing (Eisenhardt, 1989). The smaller the ownership shares of the largest shareholders, the less capable they are of having proper control over management (Balsmeier and Czarnitzki, 2017).

In contrast, if the ownership shares of the largest shareholders are big enough, they would have both sufficient incentives and the ability to monitor and discipline management, thereby minimizing the agency costs (Shleifer and Vishny, 1986, 1997). Based on the argument that higher ownership shares lead to better monitoring of the managers and lower the agency related costs, one might expect a positive link between ownership concentration and performance. Indeed, such a positive relationship is observed in a number of empirical studies (Alimehmeti and Paletta, 2012; Lee, 2008). However, whilst alleviating the agency conflict between shareholders and managers, concentrated ownership may lead to the principal-principal problem, a conflict between the controlling and minority shareholders. In companies with concentrated ownership, controlling shareholders may act on their own benefits at the cost of the minority shareholders (expropriation hypothesis) (Barclay and Holderness, 1989; Claessens et al., 2000) or take part in potentially inefficient activities (Morck et al., 1988), thereby hindering the overall performance of the firm. Such risks might be even more exacerbated in transition countries with less developed institutions and relatively weak external control mechanisms (La Porta et al., 1999). Companies with concentrated ownership are also less capable in raising new capital, since they have to rely only on the resources of the controlling shareholder (Wang and Shailer, 2015) and hence these companies may miss important investment opportunities (Balsmeier and Czarnitzki, 2017). They may also face higher costs of capital for raising external finance, due to high risk premiums resulting from the potentially high risk of expropriation by controlling shareholders (Carney and Gedajlovic, 2002). These negative effects of concentrated ownership may as well hinder firm performance. A number of empirical studies (Lepore et al., 2017; Setia-Atmaja, 2009) reveal a negative impact of ownership concentration on firm performance. The literature therefore suggests two opposing theoretical predictions on the relationship between ownership concentration and firm performance.

Nevertheless, recent literature has frequently observed a non-linear relation between ownership concentration and performance (Balsmeier and Czarnitzki, 2017; García-Meca and Sánchez-Ballesta, 2011b). The studies argue that the impact of concentrated ownership on firm performance might not be straightforwardly positive or negative, but rather a combination of both, with a true nature of the effect being dependent on the actual level of ownership concentration. Up to a certain critical point, increased ownership concentration might positively impact firm performance due to a better monitoring of management and the resulting reduction in agency costs (Berle and Means, 1932; Jensen and Meckling, 1976). However, after this critical point, the benefits of improved monitoring might be offset by the negative effects of concentrated ownership (i.e. expropriation of minority shareholders, missed investment opportunities, etc.), thereby hindering the overall firm performance (Machek and Kubíček, 2018). This concept is supported by a number of empirical studies. Thomsen and Pedersen (2000) analyzed the data of 435 of the largest European companies and observed a bell-shape link between ownership concentration and financial performance. Another study by Balsmeier and Czarnitzki (2017) revealed an inverted U-shaped relationship between ownership concentration and performance in the case of the firms from a number of Central and Eastern European transition countries. Similar quadratic relationships were observed in the case of Korean (Lee, 2008), Chinese (Gul et al., 2010), Spanish (García-Meca and Sánchez-Ballesta, 2011b) and Czech (Machek and Kubíček, 2018) listed companies. Taking into account the above-mentioned findings, we expect to observe a similar non-linear relationship between ownership concentration and performance in the case of this sample of Russian agrifood enterprises. We therefore propose the following hypothesis:

H1: There is an inverted U-shaped association between ownership concentration and firm performance.

Another important component of ownership structure that could potentially impact firm performance is ownership identity (Kumar and Zattoni, 2019). In the context of the agency problem, it is not only important how much equity a controlling shareholder owns, but also who the controlling shareholder is - an individual, 
Table 1. Overview of the literature on the relationship between ownership structure and firm performance.

\begin{tabular}{|c|c|c|c|c|}
\hline Reference & Ownership structure & Performance $^{1}$ & $\begin{array}{l}\text { Data (No. of firms, country, } \\
\text { year) }\end{array}$ & $\begin{array}{l}\text { Observed } \\
\text { relationship }\end{array}$ \\
\hline $\begin{array}{l}\text { Machek and Kubíček } \\
\text { (2018) }\end{array}$ & ownership concentration & ROA, ROE & $\begin{array}{l}\text { 3,810 non-agri-food firms, } \\
\text { Czech Republic (2007-2015) }\end{array}$ & $\begin{array}{l}\text { inverted } \\
\text { U-shape }\end{array}$ \\
\hline Lepore et al. (2017) & ownership concentration & $\begin{array}{l}\text { Tobin's Q, ROA, } \\
\text { ROS }\end{array}$ & $\begin{array}{l}565 \text { non-agri-food firms, } \\
\text { France, Germany (2013) }\end{array}$ & negative \\
\hline $\begin{array}{l}\text { Nakano and Nguyen } \\
(2013)\end{array}$ & $\begin{array}{l}\text { ownership identity } \\
\text { (foreign own) }\end{array}$ & Tobin’s Q, ROA & $\begin{array}{l}\text { 198, non-agri-food firms, Japan } \\
(1998-2011)\end{array}$ & positive \\
\hline Alfaraih et al. (2012) & $\begin{array}{l}\text { ownership identity (state } \\
\text { own) }\end{array}$ & Tobin's Q, ROA & $\begin{array}{l}134 \text { non-agri-food firms, } \\
\text { Kuweit (2010) }\end{array}$ & negative \\
\hline $\begin{array}{l}\text { Alimehmeti and } \\
\text { Paletta (2012) }\end{array}$ & ownership concentration & ROA & $\begin{array}{l}200 \text { non-agri-food firms, Italy } \\
(2006-2009)\end{array}$ & positive \\
\hline $\begin{array}{l}\text { Fauzi and Locke } \\
(2012)\end{array}$ & $\begin{array}{l}\text { ownership identity } \\
\text { (managerial own) }\end{array}$ & ROA & $\begin{array}{l}79 \text { non-agri-food firms, New } \\
\text { Zealand }(2007-2011)\end{array}$ & positive \\
\hline $\begin{array}{l}\text { García-Meca and } \\
\text { Sánchez-Ballesta } \\
\text { (2011b) }\end{array}$ & ownership concentration & Tobin's Q & $\begin{array}{l}76 \text { non-agri-food firms, Spain } \\
(1999-2002)\end{array}$ & $\begin{array}{l}\text { inverted } \\
\text { U-shape }\end{array}$ \\
\hline $\begin{array}{l}\text { Hahlbrock and } \\
\text { Hockmann (2011) }\end{array}$ & $\begin{array}{l}\text { ownership identity } \\
\text { (agroholding own) }\end{array}$ & $\begin{array}{l}\text { total factor } \\
\text { productivity }\end{array}$ & $\begin{array}{l}76 \text { agri-food firms, Russia } \\
(2001-2007)\end{array}$ & positive \\
\hline $\begin{array}{l}\text { Le and Chizema } \\
\text { (2011) }\end{array}$ & $\begin{array}{l}\text { ownership identity (state } \\
\text { own.) }\end{array}$ & $\begin{array}{l}\text { Tobin's Q, ROA, } \\
\text { ROS }\end{array}$ & $\begin{array}{l}\text { 1,205 non-agri-food firms, } \\
\text { China (2004-2005) }\end{array}$ & positive \\
\hline $\begin{array}{l}\text { Hockmann et al. } \\
(2009)\end{array}$ & $\begin{array}{l}\text { ownership identity } \\
\text { (agroholding own.) }\end{array}$ & $\begin{array}{l}\text { labor } \\
\text { productivity }\end{array}$ & $\begin{array}{l}268 \text { agri-food firms, Russia } \\
(2001-2003)\end{array}$ & no relation \\
\hline Setia-Atmaja (2009) & ownership concentration & Tobin's Q & $\begin{array}{l}316 \text { non-agri-food firms, } \\
\text { Australia }(2000-2005)\end{array}$ & negative \\
\hline Lee (2008) & ownership concentration & Tobin's Q, ROA & $\begin{array}{l}579 \text { non-agri-food firms, South } \\
\text { Korea (2000-2006) }\end{array}$ & $\begin{array}{l}\text { inverted } \\
\text { U-shape }\end{array}$ \\
\hline Bonardo et al. (2007) & $\begin{array}{l}\text { ownership identity } \\
\text { (managerial own.) }\end{array}$ & ROA, ROE & $\begin{array}{l}66 \text { non-agri-food firms, Italy } \\
(1995-1999)\end{array}$ & $\begin{array}{l}\text { inverted } \\
\text { U-shape }\end{array}$ \\
\hline $\begin{array}{l}\text { Hockmann et al. } \\
\text { (2005) }\end{array}$ & $\begin{array}{l}\text { ownership identity } \\
\text { (agroholding own.) }\end{array}$ & $\begin{array}{l}\text { economic } \\
\text { efficiency }\end{array}$ & $\begin{array}{l}100 \text { agri-food firms, Russia } \\
\text { (2001-2003) }\end{array}$ & negative \\
\hline $\begin{array}{l}\text { Anderson and Reeb } \\
(2003)\end{array}$ & $\begin{array}{l}\text { ownership identity } \\
\text { (family own.) }\end{array}$ & Tobin's Q, ROA & $\begin{array}{l}\text { 500, non-agri-food firms, USA } \\
\text { (1992) }\end{array}$ & positive \\
\hline Lins (2003) & $\begin{array}{l}\text { ownership identity } \\
\text { (managerial own.) }\end{array}$ & Tobin's Q & $\begin{array}{l}\text { 1,433 non-agri-food firms, } 18 \\
\text { emerging countries }\end{array}$ & negative \\
\hline Sun et al. (2002) & $\begin{array}{l}\text { ownership identity (state } \\
\text { own.) }\end{array}$ & Tobin's Q, ROE & $\begin{array}{l}472 \text { non-agri-food firms, China } \\
(1994-1997)\end{array}$ & negative \\
\hline
\end{tabular}

${ }^{1} \mathrm{ROA}=$ return on assets; $\mathrm{ROE}=$ return on equity; $\mathrm{ROS}=$ return on sales.

manager, financial institution, government, business group, etc. Different types of shareholders may have different abilities and incentives to properly monitor management decisions and thereby reduce agency costs (Lee, 2008).

Managerial ownership seems to be the most controversial among different ownership types, since it has contradictory impacts on firm performance. On the one hand, managerial ownership aligns the interests of managers with those of shareholders. Since managers become one of the residual claimants of the income, they have a financial motivation to maximize the profits of the company and thus improve its performance (Jensen and Meckling, 1976). On the other hand, managerial ownership may engender entrenchment of managers, a situation when managers might use their ownership control to extract the corporate resources 
for their private benefits (Lins, 2003; Morck et al., 1988). Moreover, manager-owned companies may face financing constraints, since they cannot take advantage of equity financing and have to rely on debt only as a source of finances (Thomsen and Pedersen, 2000). The overall impact of managerial ownership on performance therefore depends on which of the two effects interest alignment versus managerial entrenchment prevails. Up to a certain level of managerial ownership, an interest alignment effect may endure, which may significantly improve firm performance. However, if managerial ownership exceeds this level, managerial entrenchment may result, thereby offsetting the positive effects of interest alignment and hindering firm performance. Based on these arguments, we propose that, in the case of this sample of Russian agri-food firms, performance might be a non-linear function of managerial ownership. This leads us to the following hypothesis:

H2a: There is an inverted U-shaped association between managerial ownership and performance.

There is much more unanimity among researchers about the impact of state ownership on firm performance. Government ownership is generally regarded as inefficient, mainly because bureaucrats responsible for the governance of state-owned companies face a lack of financial incentives, since they do not have any claims in residual income (Vickers and Yarrow, 1991). State firms also have high levels of bureaucracy, which are viewed as significantly slowing down the decision making process and hindering the overall performance of a company (Sun et al., 2002). In addition, politicians may interfere in the governance of state firms (Shleifer and Vishny, 1994) and may dictate their own conditions regarding key issues like price policies, human resources policies, etc. (Krueger, 1990; Shapiro and Willig, 1990). Moreover, government enterprises are more prone to the so-called 'soft budget constraint' syndrome, introduced by Kornai (1986). State companies may not be motivated enough to generate profit, since there is always a third party in the face of the government who can provide financial support in the case of company losses. This is especially true in the case of the Russian agri-food sector, where some of the large enterprises might play significant roles for the national food security - and therefore they're considered 'too big to fail'. On the other hand, since governments are generally relatively wealthy, state-owned companies have relative advantages in issues such as access to credit, liquidity and cost of capital (Thomsen and Pedersen, 2000). Previous literature predominantly suggests that there is a negative relationship between state ownership and firm performance. Nevertheless, we expect that this might not be true in the case of Russian agri-food companies and propose that certain levels of state ownership may actually improve performance. The Russian agri-food sector is highly subsidized, and under current institutional settings in the country, one could expect that, due to their political connections, state-owned firms may have better access to government subsidies. They may also have better chances of obtaining different types of government support, such as winning public tenders, obtaining various permissions, certificates, etc. Based on the pervious literature and above arguments, we therefore hypothesize that:

H2b: There is an inverted U-shaped association between state ownership and performance.

Business groups are another type of shareholders that can potentially affect firm performance. In the context of Russian agri-food industry, such business groups are known as agroholdings and they generally hold considerable ownership shares in member companies (Matyukha, 2017). They are also typically connected with their member firms through business ties, e.g. via vertical and/or horizontal integration (Davydova and Franks, 2015). Business groups therefore have both incentives and the potential to take an active role in the corporate governance of their affiliates (Iwasaki et al., 2018). Furthermore, members of the business groups can benefit from the intra-group transfer of technology and have access to internal capital, labor and trade markets (Belenzon et al., 2013; Wan, 2005). These benefits are even more pronounced in transition economies with relatively under-developed factor markets and institutions (Toulan, 2002). Matyukha et al. (2015) name the deficiencies in the institutional settings and market infrastructures as one of the key reasons for the existence and further evolution of agroholdings in Russia. Moreover, with the help of modern technologies, agroholdings are able to minimize the monitoring costs of the hired labor and sustain increasing returns to scale (Gagalyuk, 2017). One of the main drawbacks of business groups are the difficulties in coordination, 
potential for unfair intra-group distribution of resources and manipulation of transfer prices in favor of the controlling shareholders (Holmes et al., 2018). Existing literature on agroholdings is still immature, with empirical studies providing rather mixed results on the effects of agroholding affiliation on firm performance. Hahlbrock and Hockmann (2011) have studied the effects of agroholding membership on farm efficiency in the Belgorod region of Russia, and revealed that, on average, affiliated farms perform better in terms of efficiency compared to non-affiliated farms. On the other hand, a similar study by Hockmann et al. (2005) revealed that agroholding members have lower economic efficiency compared to independent farms. Based on the contradicting empirical evidence, we propose that agroholding ownership, similar to managerial and state ownership, might have a non-linear impact on the performances of this sample of Russian agri-food firms. We therefore hypothesize that:

H2c: There is an inverted U-shaped association between agroholding ownership and performance.

\section{Methods and data}

\subsection{Model}

Our baseline regression model is expressed as follows:

$$
\text { Firm performance }=\alpha_{0}+\alpha_{1} \text { Ownership structure }+\alpha_{2} \text { Control variables }+\varepsilon
$$

Fixed effects and random effects are the two models that are most widely used in the context of panel data analysis. Using random effects models is relevant when the data represents a sub-sample of the population (Greene, 2012) and if there is a low variation in the explanatory variables over time (Wooldridge, 2002), as is the case with ownership variables. Therefore, the nature of the data used in this study suggests that a random effects model is more suitable for our analysis. In order to use a random effects model, the assumption of no correlation between the individual effects and explanatory variables should be held (Wooldridge, 2002). We used the Hausman test to check the validity of this assumption. The Hausman test could not reject the null hypothesis of 'no significant correlation between individual effects and regressors', even at the 10\% significance level, pointing to the appropriateness of the random effects model for our data.

De Hoyos and Sarafidis (2006) argue that panel-data models are likely to encounter an issue of crosssectional dependence in the error terms. Such likelihood is especially high for panels where the number of time periods is smaller than the number of cross-sectional observations. To overcome this issue, we re-ran our model using Driscoll-Kraay robust standard errors suggested by Hoechle (2007). In addition to the cross-sectional dependence, Driscoll-Kraay standard errors are also robust to heteroscedasticity and autocorrelation (Hoechle, 2007).

One of the potential issues that can arise when studying the relationship between ownership structure and performance is the presence of endogeneity, in which case the OLS regression might lead to biased results. To account for potential endogeneity, we follow the studies of Carter et al. (2003), Campbell and Mínguez-Vera (2008), and Marinova et al. (2016) and employ a two-stage least squares (2SLS) method. Running a 2SLS model requires an instrumental variable that is correlated with ownership structure but does not correlate with an error term. However, most variables that correlate with ownership structure are other governance factors that are already included in the model. This makes the finding of a valid instrument, especially in the framework of corporate governance, a very difficult task (Adams and Ferreira, 2009). Faced with such an issue, we follow the studies by Caramanis and Lennox (2008) and García-Meca and Sánchez-Ballesta (2011a) and treat the first lags of the ownership structure variables as instrumental variables. Firm performance, ownership structure and control variables used in this study are described in Table 2 and explained in detail in the following sub-section. 
Table 2. Variables and descriptions.

\begin{tabular}{|c|c|}
\hline Variables & Description \\
\hline \multicolumn{2}{|c|}{ Panel A: dependent variables } \\
\hline Return on assets (ROA) & net income / total assets \\
\hline Return on sales (ROS) & net income / sales \\
\hline \multicolumn{2}{|c|}{ Panel B: explanatory variables } \\
\hline CR1 & percentage of shares held by the largest shareholder \\
\hline CR3 & percentage of shares held by largest three shareholders \\
\hline SHARE_DIR & $\begin{array}{l}\text { percentage of shares held by the largest shareholder, if the largest } \\
\text { shareholder is an executive director }\end{array}$ \\
\hline SHARE_GOV & $\begin{array}{l}\text { percentage of shares held by the largest shareholder, if the largest } \\
\text { shareholder is the state }\end{array}$ \\
\hline SHARE_AGHL & $\begin{array}{l}\text { percentage of shares held by the largest shareholder, if the largest } \\
\text { shareholder is an agroholding }\end{array}$ \\
\hline \multicolumn{2}{|l|}{ Panel C: control variables } \\
\hline \multicolumn{2}{|l|}{ Board characteristics } \\
\hline BSIZE & the total number of directors in the boardroom \\
\hline BOD_IND & percentage of independent directors in the boardroom \\
\hline BOD_DIV & percentage of female directors in the boardroom \\
\hline \multicolumn{2}{|l|}{ Firm characteristics } \\
\hline FAGE & the number of years since the firm was first registered by the state \\
\hline FSIZE & natural logarithm of the firm's total assets \\
\hline LEVERAGE & total debt / total assets \\
\hline
\end{tabular}

\subsection{Variables}

\section{- Firm performance}

The literature suggests two main measures of firm performance: market-value-based indicators (e.g. Tobin's Q) and accounting-based-indicators (e.g. return on assets, return on sales). Due to the unavailability of market-based variables for our sample, this study focuses only on accounting-based ratios. For the robustness of regression results, we employ two measures of performance: return on assets (ROA) and return on sales (ROS). Both measures are widely used in the corporate governance literature as a proxy for firm performance (Adams and Ferreira, 2009; Liu et al., 2014).

\section{- Ownership structure}

Ownership structure is composed of two different components: ownership concentration and ownership identity. In line with the previous studies (Lee, 2008; Nguyen et al., 2015), we define the ownership concentration as the percentage of shares owned by the largest shareholder (CR1) and the percentage of shares owned by the three largest shareholders (CR3).

Ownership identity is represented by three different shareholder types that seem to be most relevant in the Russian context (Davydova and Franks, 2015; Iwasaki et al., 2018), namely: managerial ownership (SHARE_DIR), state ownership (SHARE_GOV) and agroholding ownership (SHARE_AGHL).

\section{- Control variables}

Besides ownership structure, firm performance can also be explained by other factors. We control for such factors and include board- and firm-level characteristics in our regression model. 
At the board level, we control for the board size (Yermack, 1996), measured as a total number of directors (BSIZE); board independence (Black and Kim, 2012), measured by the percentage of independent directors (BOD_IND); and board diversity (Liu et al., 2014), indicated by the percentage of female directors (BOD_ DIV) in the boardroom.

With respect to firm-level characteristics, we control for firm size (FSIZE), measured by the natural logarithm of the total assets (Marinova et al., 2016); firm age (FAGE), measured by the number of years since the company was first officially registered by the state (Reddy et al., 2008); and leverage (LEVERAGE), measured as a ratio of total debts to total assets (Schorr and Lips, 2019).

\subsection{Data}

The empirical analysis in this study is based on a unique panel data of 203 corporate agri-food companies in Russia for the years between 2012 and 2017. All the enterprises in the sample are involved in the production and/or processing of agri-food products and represent a sub-sample of the entire agri-food production of Russia. The sample was selected using the convenience sample technique, which implies the research sample to be selected based on its ease of availability and accessibility (Etikan et al., 2016; Henry, 1990). Due to the unavailability of publicly accessible data for most of Russia's corporate agri-food enterprises, our sample therefore includes only those companies for which the data on the variables of interest were publicly available.

The main sources of data are the quarterly and annual reports as well as the financial statements of the companies that were obtained from the publicly accessible database of the 'Interfax-Corporate Information Disclosure Center (CIDC), 2 agency. Interfax-CIDC is one of the five Russian agencies that are authorized to disclose information on the country's securities market. Using these reports and statements, we manually collected a large array of variables, including the ownership stakes and identities of the largest shareholders, the size and composition of the corporate boardrooms and the companies' financial figures, among others.

Descriptive statistics of the key variables used in the study are reported in Table 3. On average, companies in the sample have a high ownership concentration, with the top-1 (CR1) and the top-3 (CR3) largest shareholders possessing approximately 61 and $77 \%$ of all ownership stakes, respectively. Among the top-1 largest shareholders are agroholdings (SHARE_AGHL), executive directors (SHARE_DIR) and the state (SHARE_GOV), with the ownership stakes on average being around 23, 19 and 4\%, respectively. In addition to already high levels, ownership concentration has been steadily growing since 2012. From 2012 to 2017, both CR1 and CR3 have increased by nearly 8 and 4\%, respectively (Figure 1).

Among the top-1 shareholders, the ownership stakes of the agroholdings also increased substantially from 2012 to 2017 , by nearly $14 \%$, whereas the ownership stake of the government dropped by almost $37 \%$ within the same time period (Figure 2).

On average, a boardroom in our sample consists of six directors, of which about 51 and $29 \%$ are independent directors and female directors, respectively (Table 3). Furthermore, on average, a firm in the sample is 16 years old, has total assets of 2.3 billion Rubles (approximately 35.7 million US\$), and a debt-to-asset ratio of around $47 \%$ (Table 3). The average values of the return on assets and return on sales are 4.7 and $5.8 \%$ respectively (Table 3). Both indicators have experienced a substantial growth from 2012 to 2015, with ROA and ROS rising by around 133 and 94\%, respectively. However, since 2015, those figures have been sharply decreasing and in just two years they returned back to the levels of 2012 (Figure 3).

Another thing to mention is that the companies' sizes, both in terms of average total assets and total sales, have skyrocketed from 2012 to 2017 . While total assets of the companies grew by nearly $68 \%$, total sales rose by about $80 \%$ during the mentioned time period (Figure 4 ).

$\overline{{ }^{2} \text { Available at: https://www.e-disclosure.ru/ (in Russian) }}$ 
Table 3. Descriptive statistics of key variables.

\begin{tabular}{lllllc}
\hline Variables $^{1}$ & Obs & Mean (\%) & Std. $^{\mathbf{2}}$ & Min. & Max. \\
\hline ROA & 1,218 & 4.7 & 0.1 & -0.85 & 0.84 \\
ROS & 1,218 & 5.75 & 0.27 & -2.26 & 2.93 \\
CR1 & 1,218 & 61 & 0.27 & 0.06 & 1 \\
CR3 & 1,218 & 76.8 & 0.21 & 0.06 & 1 \\
SHARE_DIR & 1,218 & 18.38 & 0.28 & 0 & 1 \\
SHARE_GOV & 1,218 & 3.84 & 0.18 & 0 & 1 \\
SHARE_AGHL & 1,218 & 23.45 & 0.36 & 0 & 1 \\
BSIZE & 1,218 & 6 & 1.68 & 3 & 15 \\
BOD_IND & 1,218 & 50.8 & 0.38 & 0 & 1.8 \\
BOD_DIV & 1,218 & 29.27 & 0.22 & 0 & 1 \\
FAGE & 1,218 & 16 & 6.16 & 0 & 25 \\
FSIZE & 1,218 & 12.92 & 1.57 & 7.25 & 18.87 \\
LEVERAGE & 1,218 & 47.4 & 0.31 & 0.006 & 1.83 \\
\hline
\end{tabular}

${ }^{1}$ A description of the variables can be found in Table 2.

${ }^{2}$ Std. $=$ standard deviation.

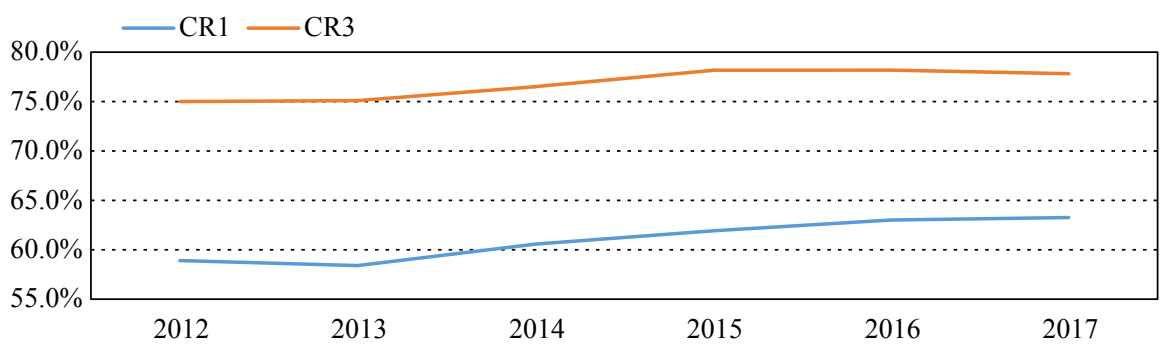

Figure 1. Ownership stakes of the largest (CR1) and three largest (CR3) shareholders.

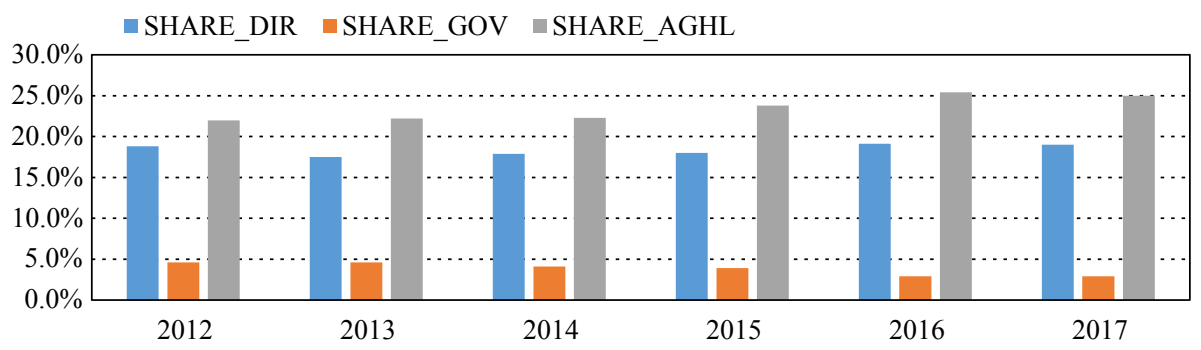

Figure 2. Ownership stakes and identities of the largest shareholders.

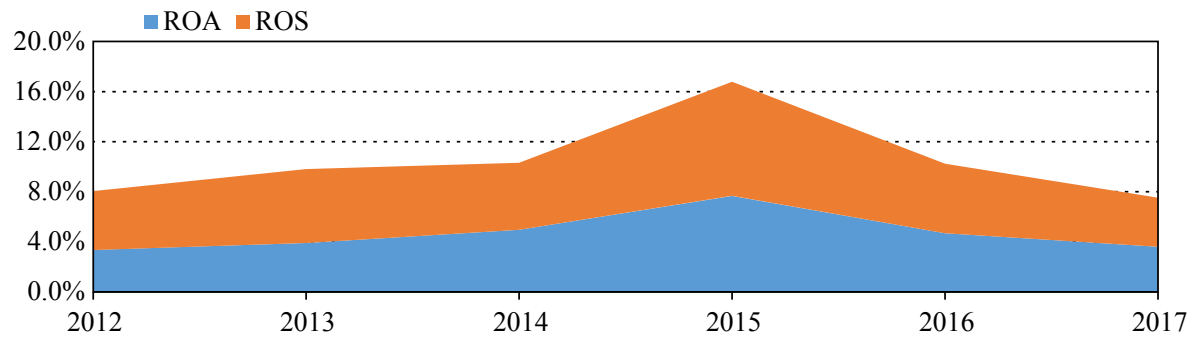

Figure 3. Return on assets (ROA) and return on sales (ROS) dynamics. 


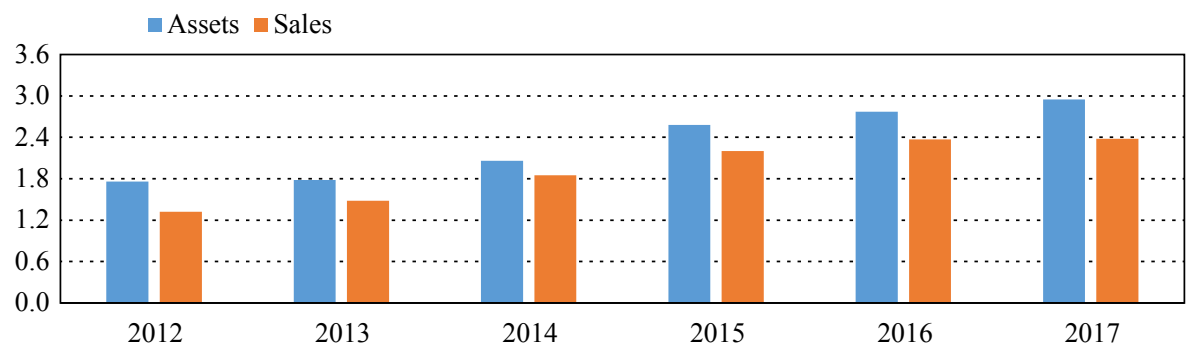

Figure 4. Total assets and total sales dynamics (billion Rubles).

To test for the potential presence of multicollinearity in the model, we estimated the correlations among all independent variables (Supplementary Table S1). The rule of thumb suggests a multicollinearity problem if variables, in their absolute terms, are correlated with a coefficient of 0.7 or above (Liu et al., 2014). The highest correlation (0.74) within our correlation matrix is observed between CR1 and CR3. However, this high correlation level is not an issue, since CR1 and CR3 are two alternative measures for ownership concentration and therefore are not simultaneously used in the model.

\section{Results and discussion}

Table 4 illustrates the results of the random effects (RE) regression with ROA and ROS as dependent variables. We observe a significant quadratic (inverse U-shaped) relationship between ownership concentration (CR1) and both the ROA and ROS, with the turning points being around 50\%. Below this turning point, a $1 \%$ growth in the ownership concentration (CR1) increases the ROA and ROS by 0.13 and $0.35 \%$ respectively. However, after the peak point of about $50 \%^{3}$, ownership concentration has an opposite effect, with a $1 \%$ increase in CR1 leading to a decrease in ROA and ROS by 0.13 and $0.35 \%$ respectively. The results are robust and similar for CR3, an alternative measure of the ownership concentration, which also exhibits an inverse U-shaped relationship with a turning point of almost 59\%. This result may be interpreted as

\footnotetext{
${ }^{3}$ The turning points of the quadratic relationship are identified using the 'utest' STATA command suggested by Lind and Mehlum (2019). The same test also supported the statistical significance of a non-linear relationship between ownership concentration and performance variables at a $5 \%$ confidence level.
}

Table 4. The impact of ownership concentration on firm performance, random effects model. ${ }^{1}$

\begin{tabular}{|c|c|c|c|c|}
\hline Variables $^{2}$ & ROA model 1 & ROA model 2 & ROS model 3 & ROS model 4 \\
\hline CR1 & $0.1325 *(0.0694)$ & & $0.3544 *(0.1833)$ & \\
\hline CR1_sqr & $-0.1331 * *(0.0562)$ & & $-0.3485^{* *}(0.1482)$ & \\
\hline CR3 & & $0.1725 * *(0.0859)$ & & $0.3876^{*}(0.2280)$ \\
\hline CR3_sqr & & $-0.1474 * *(0.0643)$ & & $-0.3382 * *(0.1706)$ \\
\hline BSIZE & $-0.0043 *(0.0023)$ & $-0.0034(0.0023)$ & $-0.0012(0.0061)$ & $0.0007(0.0060)$ \\
\hline BOD_IND & $0.0239 * *(0.0097)$ & $0.0231 * *(0.0098)$ & $0.0713 * * *(0.0256)$ & $0.0686 * * *(0.0258)$ \\
\hline BOD_DIV & $0.0479 * * *(0.0153)$ & $0.0482 * * *(0.0154)$ & $0.0897 * *(0.0407)$ & $0.0911 * *(0.0409)$ \\
\hline FAGE & $-0.0009(0.0006)$ & $-0.0008(0.0006)$ & $-0.0031 * *(0.0016)$ & $-0.003 *(0.0016)$ \\
\hline FSIZE & $0.0122 * * *(0.0025)$ & $0.0115 * * *(0.0025)$ & $0.0420 * * *(0.0066)$ & $0.0407 * * *(0.0066)$ \\
\hline LEVERAGE & $-0.1409 * * *(0.0123)$ & $-0.1401 * * *(0.0124)$ & $-0.2301 * * *(0.0323)$ & $-0.2276 * * *(0.0326)$ \\
\hline cons & $-0.0516(0.0416)$ & $-0.0674(0.0464)$ & $-0.4428 * * *(0.1085)$ & $-0.4618 * * *(0.1218)$ \\
\hline $\mathrm{R}$-squared & 0.2008 & 0.1962 & 0.1333 & 0.1292 \\
\hline Extreme points & 0.4975 & 0.585 & 0.5085 & 0.5731 \\
\hline
\end{tabular}

$1 * * *=P<0.01 ; * *=P<0.05 ; *=P<0.1 ; \mathrm{ROA}=$ return on assets; ROS $=$ return on sales; standard errors in parentheses.

${ }^{2}$ A description of the variables can be found in Table 2. 
evidence for a classical principal-agent problem. The ability and willingness of controlling shareholders to monitor and discipline the company management increases together with increased ownership share in the company. This reduces the agency conflict and related costs and has a positive impact on firm performance. However, an inverse U-shaped relationship suggests that firm performance is worsened when ownership concentration becomes too high. Balsmeier and Czarnitzki (2017) argue that low firm performance at high levels of ownership concentration illustrates high private benefits of control and weak investor protection systems, which may lead to an exploitation of minority shareholders. In this respect, on the one hand, it might be the case that controlling shareholders face high private benefits of control and do not want to share these benefits with potential investors. As a result, firms loose potential sources of external capital and therefore miss important investment opportunities, which reflects negatively on their performance. On the other hand, poor legal systems in general and weak investor protection rights in particular might result in an exploitation of the minority shareholders, which may in turn have a negative influence on overall firm performance. The average level of CR1 in our sample is nearly $61 \%$, which is higher than the turning point and lays on the descending range of the inverted U-shape. Moreover, we observe an increasing trend in the levels of ownership concentration from 2012 onwards (Figure 1). This means that, on average, corporate agri-food companies in Russia are performing below their potential. As argued above, this might be the result of forgone investment opportunities and exploitation of the minority shareholders. In this regard, corporate management and ownership of Russian agri-food enterprises should consider bringing the ownership concentration levels to the optimum range of around 50\%. This would allow firms to raise new investments, which they could use to finance new projects or modernize their existing activities. It might also considerably reduce the exploitation of minority shareholders. Taken together, these factors may have a positive impact on performance and substantially improve the production potential of the Russian agri-food industry. This concerns not only domestic but global food security as well, since Russia plays a crucial role in the world's agri-food market. Moreover, the results of this study might be interesting for Russian policy makers. In particular, they may want to consider developing programs that could incentivize the reduction of ownership concentration levels among the agri-food companies. In this regard, it would be extremely important that the government undertakes measures for improving the investor protection system in the country.

To overcome the issue of cross-sectional dependence in the error terms, we re-ran our model using the Driscoll-Kraay robust standard errors suggested by Hoechle (2007) (Supplementary Table S2). The results suggest that statistical significance of an inverse U-shaped relationship between ownership concentration (both CR1 and CR3) and performance (both ROA and ROS) is robust to the cross-sectional dependence.

Supplementary Table S2 also presents the results of a 2SLS regression, which accounts for the potential endogeneity in the model. Overall, the results of the 2SLS analysis are similar to those of the RE model, with an exception that the relationship between CR3 and ROS is not significant in the former case.

With regard to control variables, we detect a strong positive link between board independence (BOD_IND), board diversity (BOD_DIV) and firm performance (both ROA and ROS) (Table 4). The positive impact of board independence on performance is generally recognized within the corporate governance literature (Black and Kim, 2012; Dahya and McConnell, 2007). Furthermore, many countries, through their corporate governance codes, recommend that a certain portion of the corporate boards be composed of independent directors. In the case of Russia, the national corporate governance code advises that at least one-third of the corporate boards should be represented by independent directors (EBRD, 2014). The mean value of almost $51 \%$ of the BOD_IND suggests that, on average, Russian agri-food companies follow the recommendations advised by their national corporate governance code.

While there is less unanimity among researchers on the nature of the relationship between board gender diversity and performance, a growing body of literature emphasizes the importance of gender diverse boardrooms on overall firm performance (Liu et al., 2014; Tleubayev et al., 2019). Many European countries are encouraging greater female representation in the corporate boardrooms, with some countries like Norway, 
Belgium and the Netherlands even imposing affirmative action, like certain quotas for female directors (Marinova et al., 2016).

The ratio of total debt to total assets (LEVERAGE) has a strong negative impact on both ROA and ROS (Table 4). Additional monitoring provided by the debt issuers might be a substitute for poor corporate governance, which in turn might positively impact firm performance (Lopez-Valeiras et al., 2016). On the other hand, González (2013) suggests that if the cost of debt is too high, it might outweigh the positive effects of any additional monitoring by debt issuers, therefore having an overall negative impact on performance. Relatively high costs of debt in Russia, compared to developed economies, might be one of the possible reasons why we observed a negative effect of leverage on performance.

Apart from ownership concentration, the identities of the largest shareholders might also impact a firm's performance. Indeed, we observe statistically significant relationships between ownership concentration distinguished by different types of shareholders (executive directors, government and agroholdings) and performance variables (Table 5).

The results of the RE model illustrated in Table 5 suggest a significant non-linear association between ownership concentration in the hands of the SHARE_DIR and firm performance (both ROA and ROS). Ownership by SHARE_DIR first increases the firm performance, with each additional percentage owned by this type of shareholders leading to an increase in the levels of ROA and ROS by 0.08 and $0.29 \%$, respectively. This effect can be explained by the interest alignment hypothesis, which suggests that managerial ownership improves the financial incentives of managers to maximize firm performance, since managers become the residual claimants of the company income (Jensen and Meckling, 1976). However, after the certain extreme point, managers might abuse their ownership control and extract the corporate resources for their personal benefits, which could ultimately outweigh the benefits of the interest alignment effect (Lins, 2003; Morck et al., 1988). In our case, the extreme point was found to be around 34 and $38 \%$ for ROA and ROS, respectively (Table 5). After this turning point, the previous positive relationship reverses, with each $1 \%$ increase in the SHARE_DIR leading to a 0.11 and $0.38 \%$ decrease in ROA and ROS, respectively. These results are also robust to the cross-sectional dependence and endogeneity (Supplementary Table S3 and S4). An average SHARE_DIR in our sample is around $18 \%$, which is significantly below the turning point of $34 \%$. This suggests that, on average, Russian agri-food companies can still benefit from the interest alignment effect of managerial ownership. Company owners can therefore consider allocating certain shares of their stocks for their management, in the framework of various bonus or compensation options. This could potentially improve the financial performance of the firms and increase the shareholder values.

Concentrated ownership in the hands of the government has a similar, non-linear impact on one of the performance variables, ROA, with the turning point being around 39\% (Table 5). Below this peak point, a 1\% increase in government ownership (SHARE_GOV) increases the ROA by $0.22 \%$. However, after the extreme point of 39\%, each additional percentage increase in the SHARE_GOV decreases the ROA by $0.28 \%$. The relationship is not significant in the case of the ROS, another indicator of the firm performance. Supplementary Table S3 and S4 indicate that the earlier mentioned results are also robust to the cross-sectional dependence and endogeneity. In spite of a general unanimity among academics on the negative impact of state ownership on firm performance (e.g. Sun et al., 2002), our results suggest that, at least up to a certain extreme point, government ownership might actually improve firm performance. At this point, it is worth remembering that the Russian agri-food sector is massively supported by the government (Wegren et al., 2019). Taking into account high levels of corruption in Russia (Weill, 2011), one could assume that firms connected to the state have higher chances of receiving government subsidies and other types of government support (i.e. winning public tenders, obtaining various permissions, certificates, etc. This could partially explain the positive effect of up to $39 \%$ of government ownership on the performance of the agri-food companies in our sample. An average state ownership (around 4\%) is substantially below the observed peak point. 
Table 5. The impact of ownership identity on firm performance, random effects model. ${ }^{1}$

\begin{tabular}{|c|c|c|c|c|}
\hline \multirow[t]{2}{*}{ Variables $^{2}$} & \multicolumn{3}{|l|}{ Quadratic } & \multirow{2}{*}{$\begin{array}{l}\text { Linear } \\
\text { model } 4\end{array}$} \\
\hline & model 1 & model 2 & model 3 & \\
\hline \multicolumn{5}{|l|}{ ROA } \\
\hline SHARE_DIR & $0.08 *(0.04)$ & & & \\
\hline SHARE_DIR_sqr & $-0.11 * *(0.05)$ & & & \\
\hline SHARE_GOV & & $0.22 * *(0.10)$ & & \\
\hline SHARE_GOV_sqr & & $-0.28 * *(0.11)$ & & \\
\hline SHARE_AGHL & & & $0.05(0.05)$ & $0.02 * *(0.01)$ \\
\hline SHARE_AGHL_sqr & & & $-0.02(0.05)$ & \\
\hline FAGE & $-0.00(0.00)$ & $-0.00 *(0.00)$ & $-0.00(0.00)$ & $-0.00(0.00)$ \\
\hline FSIZE & $0.01 * * *(0.00)$ & $0.01 * * *(0.00)$ & $0.01 * * *(0.00)$ & $0.00 * * *(0.00)$ \\
\hline LEVERAGE & $-0.14 * * *(0.01)$ & $-0.14 * * *(0.01)$ & $-0.14 * * *(0.01)$ & $-0.15 * * *(0.01)$ \\
\hline BSIZE & $-0.00 *(0.00)$ & $-0.00 *(0.00)$ & $-0.00(0.00)$ & $-0.00(0.00)$ \\
\hline BOD_IND & $0.02 * *(0.01)$ & $0.02 * *(0.01)$ & $0.03 * * *(0.01)$ & $0.03 * * *(0.01)$ \\
\hline BOD_DIV & $0.05 * * *(0.01)$ & $0.05 * * *(0.01)$ & $0.05 * * *(0.02)$ & $0.05 * * *(0.02)$ \\
\hline _cons & $-0.02(0.04)$ & $-0.01(0.04)$ & $0.01(0.04)$ & $-0.01(0.04)$ \\
\hline R-squared & 0.2 & 0.20 & 0.19 & 0.19 \\
\hline Extreme point & 0.34 & 0.39 & & \\
\hline \multicolumn{5}{|l|}{ ROS } \\
\hline SHARE_DIR & $0.29 * *(0.11)$ & & & \\
\hline SHARE_DIR_sqr & $-0.38 * * *(0.14)$ & & & \\
\hline SHARE_GOV & & $0.03(0.27)$ & & \\
\hline SHARE_GOV_sqr & & $-0.18(0.29)$ & & \\
\hline SHARE_AGHL & & & $0.03(0.13)$ & $0.06 * *(0.03)$ \\
\hline SHARE_AGHL_sqr & & & $0.03(0.14)$ & \\
\hline FAGE & $-.00 * *(0.00)$ & $-0.00 * *(0.00)$ & $-0.00 * *(0.00)$ & $-0.00 * *(0.00)$ \\
\hline FSIZE & $0.04 * * *(0.00)$ & $0.04 * * *(0.00)$ & $0.03 * * *(0.00)$ & $0.03 * * *(0.01)$ \\
\hline LEVERAGE & $-0.23 * * *(0.03)$ & $-0.24 * * *(0.03)$ & $-0.23 * * *(0.03)$ & $-0.23 * * *(0.03)$ \\
\hline BSIZE & $-0.00(0.00)$ & $0.00(0.00)$ & $0.00(0.00)$ & $0.00(0.00)$ \\
\hline BOD_IND & $0.07 * *(0.03)$ & $0.06 * *(0.03)$ & $0.07 * * *(0.02)$ & $0.07 * * *(0.02)$ \\
\hline BOD_DIV & $0.09 * *(0.04)$ & $0.10 * *(0.04)$ & $0.10 * *(0.04)$ & $0.10 * *(0.04)$ \\
\hline _cons & $-0.36 * * *(0.09)$ & $-0.33 * * *(0.09)$ & $-0.31 * * *(0.10)$ & $-0.31 * * *(0.10)$ \\
\hline$\overline{\mathrm{R}}$-squared & 0.13 & 0.13 & 0.13 & 0.13 \\
\hline Extreme point & 0.38 & & & \\
\hline
\end{tabular}

Coming to our last ownership identity variable, ownership concentration by agroholdings (SHARE_AGHL), we could not observe any significant quadratic relationship between the SHARE_AGHL and performance (Table 5). Instead, the results of the regression analysis illustrate a statistically significant and positive linear impact of the SHARE_AGHL on both the ROA and ROS. Agroholdings seem to be more efficient owners, with a $1 \%$ increase in the SHARE_AGHL leading to 0.02 and $0.06 \%$ increase in the levels of the ROA and ROS, respectively. The results are robust to the cross-sectional dependence and endogeneity (Supplementary Table S3 and S4).

Financial efficiency of agroholding affiliates over stand-alone firms might be explained by the following factors: agroholdings are well equipped with storage facilities (Gagalyuk et al., 2018); have better access to outside capital (Matyukha et al., 2015); can benefit from the within-group transfer of technology and have an access to intra-group capital, labor and trade markets (Belenzon et al., 2013; Wan, 2005). In addition, most 
of the agroholdings are vertically integrated, thereby having an access to raw commodities supply at lower transaction costs (Hermans et al., 2017). Indeed, an empirical study by Hahlbrock and Hockmann (2011) suggests that agroholding affiliated farms in Russia have higher adoption of new technologies and therefore are more efficient compared to independent farms. Moreover, Russian agroholdings operate in the most favorable regions in terms of both agro-climatic and logistics conditions (FAO, 2009; Rada et al., 2017), which gives them comparative advantages over stand-alone firms. They are also mainly export-oriented companies (Liefert et al., 2013), which enables them to get higher commodity prices. Furthermore, Matyukha et al. (2015) argue that the opportunity of connecting individual production units provides Russian agroholdings with a strong positioning in local and regional markets. Discussions on the efficiency of agroholdings and whether agroholdings would remain as a model for the organization of agricultural production are still ongoing (Gagalyuk and Valentinov, 2019; Hermans et al., 2017; Matyukha et al., 2015). Nevertheless, the results of this study illustrate that, at least among the large-scale corporate farms of Russia, agroholding affiliated farms perform better in terms of financial performance compared to stand-alone farms. We therefore support the findings of Matyukha et al. (2015), and also assume that agroholdings will probably remain as one of the dominant business forms for agricultural production in Russia.

Although this work provides a number of contributions to the literature, it certainly has several limitations which should be addressed by future studies. Firstly, our sample selection was data-driven, meaning that the sample includes only those companies for which the necessary data was available. Moreover, the sample size of 203 companies is relatively low and may not fully reflect the corporate agri-food sector of the country. These factors may lead to a potential selectivity bias, so future studies should focus on a larger sample. Secondly, in this study we analyze the effects of ownership structure on financial performance. Future research should also consider this relationship in terms of production performance (i.e. productivity and technical efficiency) and firm market value (Tobin's Q).

\section{Conclusions}

This study contributes to the literature on corporate governance and agribusiness by providing novel empirical evidence on the impact of ownership structure on firm performance in the case of the Russian agri-food sector. We put into question the sustainability of the current structure of agri-food production in Russia, a country which plays an important role in agri-food production worldwide. Today, the bulk of Russia's agrifood production is evidently dominated by a relatively small number of corporate enterprises, which in turn are controlled by very few shareholders. Financial insolvencies by such key producers might put the food security at risk, not only at the national, but also at the global level.

The results of this study suggest an inversed U-shaped relationship between ownership concentration and performance, with a turning point being at around $50 \%$. This provides evidence for a classical agency problem and suggests that both monitoring and expropriation effects of concentrated ownership are present in the Russian agri-food context. Whichever of these two effects prevail depends on the level of ownership concentration. An average ownership concentration value of $61 \%$ among our sample suggests that the Russian agri-food sector is located in the non-optimum ownership concentration region, meaning that these firms are performing below their potential. We propose that a reduction of ownership concentration to an optimum range of around 50\% could provide investment opportunities and reduce the exploitation of minority shareholders within Russian agri-food firms, which in turn may have a significant positive impact on their performance. Considering the increasingly important role of Russia in global food security, the results of this study could be of high importance for decision makers, not only at the corporate, but also the government level. Corporate management and ownership should therefore acknowledge the importance of bringing ownership concentration levels to an optimum range. At this point, they could perhaps consider attracting new investors by opening up the sale of certain shares of company stocks. They could thereby reduce ownership concentration levels and introduce new investment opportunities to their firms. In addition to the corporate sector, policy makers at the government level may also want to consider developing measures that could potentially stimulate the reduction of ownership concentration levels in agri-food companies. In 
this respect, undertaking actions for the improvement of the investor protection system should perhaps be an inalienable part of these measures.

We also observe similar, non-linear relationships between the ownership concentrations in the hands of the executive directors and the government and firm performance. In both cases, the average values of the ownership concentration are far below the peak points. This suggests that Russian agri-food companies can benefit from the distribution of a certain number of their stocks to the executive directors.

Lastly, the ownership concentration by agroholdings has a strong positive, linear impact on performance. Agroholdings are relatively new and rapidly emerging models for the organization of agri-food production in Russia, particularly because of their role as a substitute for the poor institutional setting and market infrastructure in the country. Discussions on the superiority of agroholdings as a model for the organization of agri-food production and on the future existence of agroholdings in Russia are still ongoing. Nevertheless, based on the current evidence, agroholding affiliates seem to have better performance compared to independent companies. In this regard, further, more in-depth research is needed to allow us to understand which particular attributes of agroholding affiliated firms make them better performers compared to stand-alone firms.

\section{Supplementary material}

Supplementary material can be found online at https://doi.org/10.22434/IFAMR2019.0184

Figure S1. The share of corporate farms in the structure of the gross agricultural production in Russia from 1990 to 2018.

Table S1. Correlation matrix of independent variables.

Table S2. The impact of ownership concent ration on firm performance.

Table S3. The impact of ownership identity on firm performance, random effects model with Driscoll-Kraay robust standard errors.

Table S4. The impact of ownership identity on firm performance, two-stage least squares model.

\section{References}

Adams, R.B. and D. Ferreira. 2009. Women in the boardroom and their impact on governance and performance. Journal of Financial Economics 94(2): 291-309.

Agroinvestor. 2018a. 10 largest companies produced 58\% of broiler meat in the country (10 крупнейших компаний выпустили 58\% мяса бройлера в стране. Available at: https://tinyurl.com/sn7ofp4 (in Russian)

Agroinvestor. 2018b. Top 25 Russian meat producers. Market leaders will continue to consolidate (Ton25 крупнейших российских производителей мяса. Лидеры рынка продолжат консолидачию. Available at: https://tinyurl.com/s5zkfjl (in Russian)

Alfaraih, M., F. Alanezi and H. Almujamed. 2012. The influence of institutional and government ownership on firm performance: evidence from Kuwait. International Business Research 5(10): 192-200.

Alimehmeti, G. and A. Paletta. 2012. Ownership concentration and effects over firm performance: evidences from Italy. European Scientific Journal 8(22): 39-49.

Anderson, R.C. and D.M Reeb. 2003. Founding-family ownership and firm performance: evidence from the S\&P 500. Journal of Finance 58(3): 1301-1328.

Balsmeier, B. and D. Czarnitzki. 2017. Ownership concentration, institutional development and firm performance in Central and Eastern Europe. Managerial and Decision Economics 38(2): 178-192.

Barclay, M.J. and C.G. Holderness. 1989. Private benefits from control of public corporations. Journal of Financial Economics 25(2): 371-395.

BEFL Agency. 2018. The largest owners of agricultural land in Russia for 2018 (Крупнейшие владельиьы сельскохозяйственной земли в России на 2018 год. Available at: https://tinyurl.com/ut8apyn (in Russian) 
Belenzon, S., T. Berkovitz and L.A. Rios. 2013. Capital markets and firm organization: how financial development shapes European corporate groups. Management Science 59(6): 1326-1343.

Berle, A.A. and G.C. Means. 1932. The modern corporation and private property. Macmillan, New York, NY, USA.

Black, B. and W. Kim. 2012. The effect of board structure on firm value: a multiple identification strategies approach using Korean data. Journal of Financial Economics 104(1): 203-226.

Bobojonov, I., R. Teuber, S. Hasanov, V. Urutyan and T. Glauben. 2016. Farmers' export market participation decisions in transition economies: a comparative study between Armenia and Uzbekistan. Development Studies Research 3(1): 25-35.

Bonardo, D., S. Paleari and S. Vismara. 2007. The non-linear relationship between managerial ownership and firm performance. Corporate Ownership \& Control 4(4): 18-29.

Campbell, K. and A. Mínguez-Vera. 2008. Gender diversity in the boardroom and firm financial performance. Journal of Business Ethics 83(3): 435-451.

Caramanis, C. and C. Lennox. 2008. Audit effort and earnings management. Journal of Accounting and Economics 45(1): 116-138.

Carney, M. and E. Gedajlovic. 2002. The coupling of ownership and control and the allocation of financial resources: evidence from Hong Kong. Journal of Management Studies 39(1): 123-146.

Carter, D.A., B.J. Simkins and W.G. Simpson. 2003. Corporate governance, board diversity, and firm value. The Financial Review 38(1): 33-53.

Claessens, S., S. Djankov and L.H. Lang. 2000. The separation of ownership and control in East Asian Corporations. Journal of Financial Economics 58(1-2): 81-112.

Dahya, J. and J.J. McConnell. 2007. Board composition, corporate performance, and the Cadbury committee recommendation. Journal of Financial and Quantitative Analysis 42(3): 535.

Dairynews. 2018a. The top 50 largest dairy plants of the Russian Federation includes nine new enterprises (B топ-50 крупнейших молочных заводов РФ вошли девять новых предприятий. Available at: https://tinyurl.com/s3vo4jh

Dairynews. 2018b. Top 50 Russian milk producers increased milk production by 13.7\% in 2017 (ТОП-50 производителей молока России в 2017 году увеличили производство молока на 13,7\%. Available at: https://tinyurl.com/wqzr4jx

Davydova, I. and J. Franks. 2015. The rise and rise of large farms: why agroholdings dominate Russia's agricultural sector [Возрождение крупных хозяйств в России: почему агрохолдинги доминируют в российском аграрном секторе]. Мир России 24(3): 133-159.

De Hoyos, R.E. and V. Sarafidis. 2006. Testing for cross-sectional dependence in panel-data models. The Stata Journal: Promoting Communications on Statistics and Stata 6(4): 482-496.

Deininger, K. and D. Byerlee. 2012. The rise of large farms in land abundant countries: do they have a future? World Development 40(4): 701-714.

Eisenhardt, K.M. 1989. Agency theory: an assessment and review. Academy of Management Review 14(1): 57-74.

Etikan, I., S.A. Musa and R.S. Alkassim. 2016. Comparison of convenience sampling. American Journal of Theoretical and Applied Statistics 5(1): 1-4.

European Bank for Reconstruction and Development (EBRD). 2014. Corporate governance code, Russia. Available at: https://www.ebrd.com/downloads/legal/corporate/russia_code.pdf

Food and Agriculture Organization (FAO). 2001. Mineral soils conditioned by a steppic climate. FAO, Rome, Italy. Available at: http://www.fao.org/3/y1899e/y1899e11.htm

Food and Agriculture Organization (FAO). 2009. Russian Federation-analysis of the agribusiness sector in Southern Russia. Report series No. 111. FAO, Rome, Italy.

Food and Agriculture Organization (FAO). 2017. FAOSTAT - Russian Federation country indicators. FAO, Rome, Italy. Available at: http://www.fao.org/faostat/en/\#country/185

Fauzi, F. and S. Locke. 2012. Board structure, ownership structure and firm performance: a study of New Zealand listed-firms. Asian Academy of Management Journal of Accounting and Finance 8(2): 43-67. 
Filatotchev, I., R. Kapelyushnikov, N. Dyomina and S. Aukutsionek. 2001. The effects of ownership concentration on investment and performance in privatized firms in Russia. Managerial and Decision Economics 22(6): 299-313.

Gagalyuk, T. 2017. Strategic role of corporate transparency: the case of Ukrainian agroholdings. International Food and Agribusiness Management Review 20(2): 257-278.

Gagalyuk, T. and V. Valentinov. 2019. Agroholdings, turbulence, and resilience: the case of Ukraine. Journal of East European Management Studies 24(3): 482-494.

Gagalyuk, T., V. Valentinov and F. Schaft 2018. The corporate social responsibility of Ukrainian agroholdings: the stakeholder approach revisited. Systemic Practice and Action Research 31(6): 675-698.

García-Meca, E. and J.P. Sánchez-Ballesta. 2011a. Ownership structure and forecast accuracy in Spain. Journal of International Accounting, Auditing and Taxation 20(2): 73-82.

García-Meca, E. and J.P. Sánchez-Ballesta. 2011b. Firm value and ownership structure in the Spanish capital market. Corporate Governance: the International Journal of Business in Society 11(1): 41-53.

González, V.M. 2013. Leverage and corporate performance: international evidence. International Review of Economics \& Finance 25: 169-184.

Greene, W. 2012. Econometric analysis, $6^{\text {th }}$ edition. Pearson, New York, NY, USA.

Gul, F.A., J.B. Kim and A.A. Qiu. 2010. Ownership concentration, foreign shareholding, audit quality, and stock price synchronicity: evidence from China. Journal of Financial Economics 95(3): 425-442.

Hahlbrock, K. and H. Hockmann. 2011. Does group affiliation increase productivity and efficiency in Russia 's agriculture? Evidence from agroholdings in the Belgorod Oblast. In: EAAE 2011 Congress: Change and Uncertainty; Challenges for Agriculture, Food and Natural Resources. August 30- September 2, 2011. Zurich, Switzerland.

Henry, G.T. 1990. Practical sampling: applied social and research method series. Vol. 21. The SAGE handbook of applied social research methods. Sage, Thousand Oaks, CA, USA.

Hermans, F.L.P., F.R. Chaddad, T. Gagalyuk, S. Senesi and A. Balmann. 2017. The emergence and proliferation of agroholdings and mega farms in a global context. International Food and Agribusiness Management Review 20(2): 175-186.

Hockmann, H., R. Bokusheva and I. Bezlepkina. 2009. Agroholdings membership: does that make a difference in performance? Quarterly Journal of International Agriculture 48(1): 25-46.

Hockmann, H., J. Wandel and A. Nedoborovskyy. 2005. Agroholdings in Russia: breaking the vicious circle? In: European Association of Agricultural Economists $94^{\text {th }}$ Seminar. April 9-10, 2005. Ashford, UK.

Hoechle, D. 2007. Robust standard errors for panel regressions with cross-sectional dependence. The Stata Journal: Promoting Communications on Statistics and Stata 7(3): 281-312.

Holmes, R.M., R.E. Hoskisson, H. Kim, W.P. Wan and T.R. Holcomb. 2018. International strategy and business groups: a review and future research agenda. Journal of World Business 53(2): 134-150.

Iwasaki, I. and S. Mizobata. 2019. Ownership concentration and firm performance in European emerging economies: a meta-analysis. Emerging Markets Finance and Trade 56(1): 32-67.

Iwasaki, I., S. Mizobata and A. Muravyev. 2018. Ownership dynamics and firm performance in an emerging economy: a meta-analysis of the Russian literature. Post-Communist Economies 30(3): 290-333.

Jensen, M.C. and W.H. Meckling. 1976. Theory of the firm: managerial behavior, agency costs and ownership structure. Journal of Financial Economics 3(4): 305-360.

Kornai, J. 1986. The soft budget constraint. Kyklos 39(1): 3-30.

Krueger, A.O. 1990. Government failures in development. Journal of Economic Perspectives 4(3): 9-23.

Kumar, P. and A. Zattoni. 2019. Farewell editorial: exiting editors' perspective on current and future challenges in corporate governance research. Corporate Governance: an International Review 27(1): 2-11.

La Porta, R., F. Lopez-De-Silanes and A. Shleifer. 1999. Corporate ownership around the world. The Journal of Finance 54(2): 471-517.

Le, T. and A. Chizema. 2011. State ownership and firm performance: evidence from Chinese listed firms. Organizations \& Markets in Emerging Economies 2(2): 72-90.

Lee, S. 2008. Ownership structure and financial performance: evidence from panel data of South Korea. Corporate Ownership \& Control 6(2): 254-267. 
Lepore, L., F. Paolone, S. Pisano and F. Alvino. 2017. A cross-country comparison of the relationship between ownership concentration and firm performance: does judicial system efficiency matter? Corporate Governance: The International Journal of Business in Society 17(2): 321-340.

Li, W.X., C.C.S. Chen and J.J. French. 2012. The relationship between liquidity, corporate governance, and firm valuation: evidence from Russia. Emerging Markets Review 13(4): 465-477.

Liefert, O., W. Liefert and E. Luebehusen. 2013. Rising grain exports by the former Soviet Union region: causes and outlook. Economic Research Service/USDA, Washington, DC, USA.

Liefert, W.M., O. Liefert, R. Seeley and T. Lee. 2019. The effect of Russia's economic crisis and import ban on its agricultural and food sector. Journal of Eurasian Studies 10(2): 119-135.

Lind, J. and H. Mehlum. 2019. UTEST: Stata module to test for a U-shaped relationship. Department of Economics, Boston College, Boston, MA, USA.

Lins, K.V. 2003. Equity ownership and firm value in emerging markets. The Journal of Financial and Quantitative Analysis 38(1): 159.

Liu, Y., Z. Wei and F. Xie. 2014. Do women directors improve firm performance in China? Journal of Corporate Finance 28: 169-184.

Lopez-Valeiras, E., J. Gomez-Conde and T. Fernandez-Rodriguez. 2016. Firm size and financial performance: intermediate effects of indebtedness. Agribusiness 32(4): 454-465.

Machek, O. and A. Kubíček. 2018. The relationship between ownership concentration and performance in Czech Republic. Journal of International Studies 11: 177-186.

Marinova, J., J. Plantenga and C. Remery. 2016. Gender diversity and firm performance: evidence from Dutch and Danish boardrooms. The International Journal of Human Resource Management 27(15): 1777-1790.

Matyukha, A. 2017. Business groups in agriculture impact of ownership structures on performance : the case of Russia's agroholdings. Studies on the Agricultural and Food Sector in Transition Economies No. 85. Leibniz Institute of Agricultural Development in Transition Economies (IAMO), Halle (Saale), Germany.

Matyukha, A., P. Voigt and A. Wolz. 2015. Agro-holdings in Russia, Ukraine and Kazakhstan: temporary phenomenon or permanent business form? Farm-level evidence from Moscow and Belgorod regions. Post-Communist Economies 27(3): 370-394.

Morck, R., A. Shleifer and R.W. Vishny. 1988. Management ownership and market valuation: an empirical analysis. Journal of Financial Economics 20: 293-315.

Nakano, M. and P. Nguyen. 2013. Foreign ownership and firm performance: evidence from Japan's electronics industry. Applied Financial Economics 23(1): 41-50.

Nguyen, T., S. Locke and K. Reddy. 2015. Ownership concentration and corporate performance from a dynamic perspective: does national governance quality matter? International Review of Financial Analysis 41: 148-161.

Paniagua, J., R. Rivelles and J. Sapena. 2018. Corporate governance and financial performance: the role of ownership and board structure. Journal of Business Research 89: 229-234.

Rada, N., W. Liefert and O. Liefert. 2017. Productivity growth and the revival of Russian agriculture. No. 1477-2017-586. Economic Research Service/USDA, Washington, DC, USA.

Reddy, K., S. Locke, F. Scrimgeour and A. Gunasekarage. 2008. Corporate governance practices of small cap companies and their financial performance: an empirical study in New Zealand. International Journal of Business Governance and Ethics 4(1): 51.

Sánchez-Ballesta, J.P. and E. García-Meca. 2007. A meta-analytic vision of the effect of ownership structure on firm performance. Corporate Governance: an International Review 15(5): 879-892.

Schorr, A. and M. Lips. 2019. The optimal capital structure of Swiss dairy farms. Agricultural Finance Review 79(3): 323-337.

Setia-Atmaja, L.Y. 2009. Governance mechanisms and firm value: the impact of ownership concentration and dividends. Corporate Governance: an International Review 17(6): 694-709.

Shapiro, C. and R. Willig. 1990. Economic rationales for the scope of privatization. Discussion paper No. 41. Woodrow Wilson School, Princeton, NJ, USA. 
Shleifer, A. and R.W. Vishny. 1986. Large shareholders and corporate control. Journal of Political Economy 94(3): 461-488.

Shleifer, A. and R.W. Vishny. 1994. Politicians and firms. The Quarterly Journal of Economics 109(4): 995-1025.

Shleifer, A. and R.W. Vishny. 1997. A survey of corporate governance. Journal of Finance 52: 737-783.

Sun, Q., W.H.S. Tong and J. Tong. 2002. How does government ownership affect firm performance? Evidence from China's privatization experience. Journal of Business Finance \& Accounting 29(1-2): 1-27.

Thomsen, S. and T. Pedersen. 2000. Ownership structure and economic performance in the largest European companies. Strategic Management Journal 21(6): 689-705.

Tleubayev, A., I. Bobojonov, T. Gagalyuk and T. Glauben. 2019. Board gender diversity and firm performance: evidence from the Russian agri-food industry. International Food and Agribusiness Management Review 23(1): 35-53.

Toulan, O.N. 2002. The impact of market liberalization on vertical scope: the case of Argentina. Strategic Management Journal 23(6): 551-560.

United States Department of Agriculture (USDA). 2018a. Russia: agricultural economy and policy report. USDA GAIN Report No. RS1819. USDA, Washington, DC, USA.

United States Department of Agriculture (USDA). 2018b. Russia: livestock and products annual. USDA GAIN Report No. RS1828. USDA, Washington, DC, USA.

Uzun, V., N. Shagaida and Z. Lerman. 2019. Russian agriculture: growth and institutional challenges. Land Use Policy 83: 475-487.

Vickers, J. and G. Yarrow. 1991. Economic perspectives on privatization. Journal of Economic Perspectives 5(2): 111-132.

Wan, W.P. 2005. Country resource environments, firm capabilities, and corporate diversification strategies. Journal of Management Studies 42(1): 161-182.

Wang, K. and G. Shailer. 2015. Ownership concentration and firm performance in emerging markets: a meta-analysis. Journal of Economic Surveys 29(2): 199-229.

Wegren, S.K. 2018. The 'left behind': smallholders in contemporary Russian agriculture. Journal of Agrarian Change 18(4): 913-925.

Wegren, S.K., A.M. Nikulin and I. Trotsuk. 2019. Russian agriculture during Putin's fourth term: a SWOT analysis. Post-Communist Economies 31(4): 419-450.

Weill, L. 2011. How corruption affects bank lending in Russia. Economic Systems 35(2): 230-243.

Wooldridge, J.M. 2002. Econometric analysis of cross section and panel data. MIT Press, Cambridge, MA, USA.

Yastrebova, O. 2005. Nonpayments, bankruptcy and government support in Russian agriculture. Comparative Economic Studies 47(1): 167-180.

Yermack, D. 1996. Higher market valuation of companies with a small board of directors. Journal of Financial Economics 40(2): 185-211. 